\title{
Desmoplastic Small Round Cell Tumor
}

National Cancer Institute

\section{Source}

National Cancer Institute. Desmoplastic Small Round Cell Tumor. NCI Thesaurus. Code C8300

An aggressive malignant soft tissue neoplasm of uncertain differentiation. It is characterized by a recurrent chromosomal translocation $\mathrm{t}(11 ; 22)(\mathrm{p} 13 ; \mathrm{q} 12)$ and the presence of small round cells in a desmoplastic stroma. It usually affects children and young adults. The most common site of involvement is the abdomen. Patients usually present with abdominal distention, pain, ascites, and a palpable abdominal mass. The prognosis is usually poor. 